\title{
Juxtaposing adherence to COVID-19 regulations and practising proper burial rites: a case study of Zulu Traditional Religion
}

\author{
Evangeline Bonisiwe Zungu \\ Faculty of Humanities, Department of African Languages \\ University of the Witwatersrand, South Africa \\ ORCID: https://orcid.org/0000-0003-4837-9155 \\ Email: boni.zungu@wits.ac.za \\ Doi: https://doi.org/10.46222/pharosjot.102.23
}

\begin{abstract}
The recent COVID-19 pandemic took the world by storm. The rate of infection and prevalence of death struck fear in the hearts of many across the globe. The high likelihood of infection required continual testing whilst the trauma of bereavement left many distraught. For traditionalists, a principal concern was whether they would be permitted to exhaustively practise their burial rites in the course of mourning their loved ones. The importance of the custom, as it is believed, is to prevent unsettled feelings in family members. This article is aimed at stimulating consideration, reflection and understanding of the concerns experienced by traditional societies surrounding COVID-19 regulations and the non-performance of important burial rites. Surviving family members experience troubled thoughts as a result of the fear of repercussions, which may include the living-dead withholding their protection of the family which consequently will cause ailments and accidents. This article will utilise inductive thematic analysis to interpret the data collected .
\end{abstract}

Keywords: burial rites, COVID-19, death, African Traditional Religion, Zulu culture.

\section{Introduction}

The onslaught of the Coronavirus (COVID 19), , and its resultant infections and deaths startled the world. As a result of the uncertainty the world experienced stockpiling, job insecurity, increased depression and stress-eating.The World Health Organisation and the National Department of Health of South Africa attempted to adequatelyexplain the manner in which the virus could be contracted. Within this category was mentioned the risk of contraction at funerals which were commonly referred to as 'super-spreader events'. The suddenness of the virus's appearance meant no time was allowed for the remodelling or the evolution of the rituals. The only expectation was adherence to the prescribed regulations or facing a criminal record.

Despite the high risk of transmissibility and its devastating mortality rate, traditional societies were steadfast in their adherence to African Traditional Religion, and its corresponding burial rites. In order to avoid the contradictions between what the National Coronavirus Council regulations and burial rituals there is a much needed reformulation of burial rites in South Africa. Souza \& Souza (2019: 7) mentions that:

The role funeral rituals play in psychological maturation, as they help individuals to face concrete loss and trigger the grieving process, allows people to publicly manifest their grief. 
Similarly, Cardoso, et al (2020: 1) asserts that, "these rituals help survivors to overcome the critical moment, decreasing the risk of complicated grief". COVID-19 pandemic regulations "constrains, restricts and impedes the performance of these ancient customs", (Jaja, et al., 2020: 389).

\section{Funeral Mourning}

In most African societies there is a cultural belief that to be in the world of the dead confers supernatural powers over those in the world of the living; such as, the ability to bless or to curse, and to give life or to take life (Ekore \& Lanre-Abass, 2016:370). As death is perceived as the continuation of life performance of the burial rituals encourages the deceased to be a good ancestor and to become a guardian angel and a protector of his/her family members (Idowu, 1962; Awolalu \& Dopamu, 1979; Gbenda, 2005).

African people are notoriously communal in orientation, thus the bereaved families attempt to continue that cultural trait after the death of a loved one. Funeral rituals are at the centre of African socio-cultural systems which ensure unity and solidarity post-funeral. "By means of myths and rituals they were able to entertain collective sentiments and express a sense of social unity. Thus, when a people come together to mourn the deceased in their own traditional way, they unwittingly gain a renewed sense of themselves and the legitimacy of social organisation. Occasions like these enable the reunion of people and the reassertion of the solidarity" (Ademiluka, 2009:17).

From my years of conducting research and growing up in a traditional society, in Zululand, it was always clear that the funeral rituals differ depending on the level of the person who has passed, however, they are all equally important. Even if a child is stillborn funeral rituals need to be performed accordingly. The body needs to be brought home and the child be given a name so that they rest peacefully and join the ancestors. The name-giving ceremony is very important as it endows the stillborn child, with personhood. African people have respect for human life, the duration of which begins at conception. This respect is evident in the special treatment afforded to pregnant women, as well as the procurement of special medicines which are aimed at protecting the foetus from evil spirits. Similarly, this is evidenced in the performance of a cleansing ritual for the mother, in the same way it would be performed if the foetus had lived.

The death of a married man is treated with utmost care. In Zulu societies ukufih/wa komnumzane (burial of a married man) often means loss of income and protection. When the head of the family passes, the wife and the children are left to fend for themselves. The performance of the proper rituals is thus believed to appease the deceased and ensure the continuation of provision and protection by the deceased from beyond the grave. Likewise, the family member carrying ihlahla lomlahlankosi ${ }^{1}$ tells the deceased to continue looking after the children (which in this case includes the wife).

At the highest level, is the death of a King. The recent passing of the AmaZulu King, Goodwill Zwelithini kaBhekuzulu is one such example. His passing was not announced immediately to adhere to an age old tradition of the Zulu nation. This was followed by a string of funeral rituals which are compulsory. The ukutshalwa kweNkosi (the interment of a King) has opened the eyes of many and refreshed the knowledge they previously had about the whole process. These rituals have to be followed so as to protect the nation and ensure the continuation of the monarchy. It is believed, that failure to adhere to the prescribed rituals will cause the demise and destruction of the kingdom. One such ritual is the time of interment, namely, night time. This is carried out by a cohort of trusted men from the royal household and the regiments surrounding the homestead, who singing the royal dirges the whole night. Though there were

\footnotetext{
${ }^{1}$ Umlahlankosi is a buffalo thorn tree. It is used to bring the spirit of the deceased home from where the person died.
} 
strict rules and regulations imposed because of the COVID-19 pandemic, some of the rituals had to be performed. Traditionalist Africans in South Africa believe their family members do not die and disappear, more so for a fallen monarch. He is considered to not have died but rather, 'he shed his skin' (iNdlondlo² yebuzile - the feathered black mamba has shed its skin), which speaks to his new identity as living-dead. Diop, a Senegalese poet cited in Olupona (2000:54), observed that in Africa:

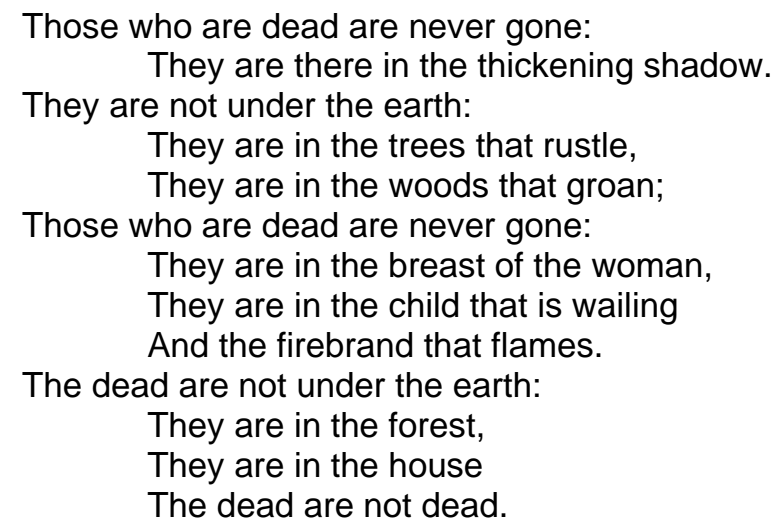

The above poem sums up the thought-processes and beliefs, within the religion of traditional societies. It also speaks to the psyche of the Zulu people, specifically referring to the destiny of the soul and the imagined life in the hereafter. It highlights life in the hereafter as a staunch reality and not as a distant illusion. "Zulu people are generally eager to please their living-dead and to keep a good relationship with them" (Zungu, 2021: 75).

This article juxtaposes the importance of burial rituals as part of culture and African Traditional Religion, with adherence to COVID-19 lockdown regulations, which are felt as an imposition and an infringement of the rights to practise one's religion. The article argues that as important as adhering to COVID-19 regulations is in order to curb the spread of the coronavirus, the nonperformance of burial rituals is deeply concerning to the Zulu traditional people. These regulations confused and negatively affected the psyche of traditional people. Notwithstanding their necessity for the safety of the community at large, for adherents of African Traditional Religion they have disrupted the transition of the departed from the physical realm to the spirit realm. The article attempts to respond to the following questions: To what extent has nonperformance of burial rites instilled fear of the wrath of the living-dead on the surviving relatives? How does not fulfilling last homage to the departed exacerbate the feelings of indignation and prolong emotional healing?

\section{Literature Review}

Different African scholars (Omonisi 2020; Ngubane 2004; Mbiti 1969; Zungu 2016 ) have conducted numerous studies on African burial rituals and agree on their importance in ushering the deceased into the hereafter. Similarly, an emphasis is placed on death being a beginning of life in the spirit as opposed to its depiction as the end. "Death in African religions is one of the last transitional stages of life requiring passage rites, this too takes a long time to complete. The deceased must be "detached" from the living and make as smooth a transition as possible to the next life, as the journey to the world of the dead has many interruptions" (Jaja et al., 2020: 391). The burial rituals provide a cathartic platform and outlet for surviving family members to freely express their pain and grief for the deceased (Shino, 1997). Each African community has a specific way of sending off the deceased to the land of the living dead. The belief that they are dead in the flesh but are 'alive' spiritually qualifies them to be living-dead.

\footnotetext{
${ }^{2}$ His izibongo (praises) mention that he is indeed 'Indlondl enophaph' ekhanda kaMenzi' (Menzi's feathered black mamba). Menzi here is King Senzangakhona who was King Shaka's father.
} 
The living family members strongly believe that the living-dead act as guardian angels on condition that the living family members live peacefully within the homestead (Zungu, 2016). Since death does not mean a complete separation between the living and the dead, the corpse is always treated with respect. The most important aspect of the death rituals is making sure that there is 'continuity of life' even in the hereafter (Barasa \& Shitandi, 2020; Mbiti, 1969).

Equally important is the respect for death that African people have, as "to die in the traditional belief is like going back home where you belong, thus the use of the words: ukugoduka, ukuya kobabamkhulu, ukudlula, ukuya kwelamathongo, this implies that when one dies one rejoins old relatives and friends who had gone before. When going home one needs respect, dignity and proper burial" (Ngubane, 2004:171-172). The respect that the living family members have for their departed family member continues even beyond the grave. "These funeral rites and rituals are an expression of the people's thoughts, emotions, social organisation and cultural identity" (Onu, 2019:99).

The strict COVID-19 regulations have affected many African societies and the manner in which burials are performed. The imposition of measures such as social distancing and the support of the bereaved from a distance, go against the spirit of Ubuntu and the communal nature of the African people. Without breaking the rules intentionally, African people find this way of life distant and cold. The presence of compliance does not mean acceptance, instead it is focused on conformity and submission to the authorities the relevant laws. African people attach huge significance and religious meaning to African traditional bereavement rituals (Mokhutso, 2019). Even as communities move towards modernisation and westernisation, traditional people still adhere to the prescribed funeral rituals so that cohesion, peace and solidarity can be restored within the family and the society at large (Nyawose, 2000).

The challenge posed by the COVID-19 pandemic is mainly to the elderly, the very people who are at the centre of the burial rituals. Regulations do not allow for more than 60 people at a funeral as "the virulence and pathogenicity of COVID-19 are severe in the elderly and people with co-morbidity" (Jaja et al., 2020:1077). There are a lot of misunderstandings when it comes to the control of the virus, so much so when people are in pain and grieving. "These control strategies had put a lot of pressures on the weak mortuary services in Africa, altered the traditional methods of observing burial rites, mourning and grieving" (Omonisi, 2020:1). The problem is not that people want to break the law, it is that the health guidelines "involves breaking their customs and traditions as regards to burial rites" (Akwa \& Maingi, 2020:1) which is frustrating for them.

\section{Theoretical Framework}

This article adopted the sociocultural approach which is founded on the premise that people use their experiences and culture to shape the way they do things. This theory which encompasses a bifold model of considering cultural influences and physiological factors was developed by Vygotsky in the 1930s. It is founded on the social constructivist paradigm which acknowledges that knowledge is socially constructed through interaction and is shared by individuals (Bryman, 2001). This theory is more applicable to this article as it is about the experiences and feelings of the surviving relatives exerted by COVID -19 lockdown regulations on burial rituals of the Zulu people.

\section{Methodology}

The time frame for this study was from March 2020, when the COVID-19 lockdown regulations were enforced in South Africa. The article utilised news on SABC, eNCA CNN etc., and any other openly accessible news channel. In utilising the qualitative approach, there was be an inclusion of desktop research and first-hand testimonies of family members who had experienced The interviews were conducted telephonically due to the lockdown regulations and the need for social distancing as prescribed by law. 


\title{
Discussion
}

Funeral rituals are at the core of the Zulu peoples' religion (Hexham, 1997) and their thoughtpattern and philosophy (Berglund, 1976). This is also evident in other African societies like the Basuto of Lesotho and Baganda of Uganda (Chihota, 2003; Mulambuzi, 1997) as well as a staunch belief in the ancestral spirits and their presence within the household (Magesa, 1997; Nwachuku, 1994).

Radcliffe-Brown cited in Bockie (1993:104) says that:

For the society a death is the loss of one of its members, one of its constituent parts. A person occupies a definite position in society, has a certain share in the social life, is one of the supports of the network of social relations. His death constitutes a partial destruction of the social cohesion, the normal social life is disorganized, the social equilibrium is disturbed. After the death the society has to organize itself anew and reach a new condition of equilibrium.

In most African societies there is a big emphasis placed on how the person is buried. It is believed that, for instance, if a person disappears and dies without his family's knowledge and does not get a proper burial, his soul lingers on the earth and is always seen at night, troubling strangers (Zungu, 2021). This can be avoided through the performance of proper rituals.

Burial is the most common method of dealing with the corpse. Mbiti (1969:154) states that "some societies bury the body inside the house where the person was living at the time of death; others bury it in the compound where the homestead is situated; others bury the body behind the compound; and some do at the place where the person was born." He further says that "people view death paradoxically: it is a separation but not annihilation, the dead person is suddenly cut off from the human society and yet the corporate group clings to him." Certain rituals have to be performed for a person to be at peace and to cross over. Bockie (1993:106) says on the importance of performing the rituals:

\begin{abstract}
Spiritually, the dead remains part of the old living community as well as the new community of the ancestors, until all the rites of adjustment to his departure are properly observed and completed. In the meantime, he remains a public charge to those closely related to him, in the sense that they adjust their way of life according to his present status namely, 'betweenness'. While on the one hand he belongs to both communities, the living and the dead, on the other hand, he belongs to neither. He is a member without identity.
\end{abstract}

Olupona (2000:54) points out that, "Death is a mere passage from the human world to the spirit world. The passage enhances the spiritual powers so that one could now operate in the human environment, and especially in the human family, as a guardian, protective spirit/power/influence."

When a person dies iphoyisa lenkosi is the one that announces the death to the whole community (ukuhlaba umkhosi). Very early on the day of the funeral iphoyisa lenkosi will stand on the hill and shout at the top of his voice, saying for instance, "kwaNgidi eMbitane, yelekelelani, konakele" (at the Ngidis in Mbitane, there is a crisis. Come and help out). Then people know that they need to go and dig the grave because somebody has passed away.

The mourning family has to use muti to cleanse themselves of bad luck after the funeral. Three months after the person has died, a cleansing ceremony is performed ukuxokozela ${ }^{3}$ (to make noise) if a woman has died or ukujikijela 4 (to throw) if a man has died. Ukujikijela involves men of that community going hunting before eating the slaughtered goat. A couple of months after

\footnotetext{
${ }^{3}$ This is important because during the mourning period family members have to speak in low voices;

${ }^{4}$ This is the first hunting trip at the end of the mourning period (if a man died), hunters 'throw' knobkerries at wild animals
} 
this another ritual is performed in which a cow is slaughtered; isihlangu for a man or isidwaba for a woman. Isihlangu (a fighting shield) is to make sure that the man has some form of protection on his way to his ancestors. Isidwaba (pleated skirt made out of cow hide), to dress the women appropriately when she is admitted to her in-laws in the hereafter. After a year, then, a ritual of ukubuyisa is performed to bring the spirit of the dead person home to his family (Zungu, 2021).

African peoples both acknowledge and deny the disruption of death. A person dies and yet he continues to live. The surviving relatives hold on to the deceased and remember him (Mbiti, 1969). The importance of the burial rites within Zulu traditional society can never be overemphasised. The outbreak of the coronavirus gravely disrupted these customs.

For instance, ukulanda isidumbu from the mortuary entails 'talking to' the deceased using umlahlankosi (buffalo thorn) branch. This means that he/she must be informed of each and every move the hearse he is in makes. If the car stops at the robot, if it is stuck in traffic, if it is crossing a river, he/she has to be informed. It is believed that if he is not informed, he may be "left" in these areas. Since the coronavirus outbreak, the body is accompanied by the hearse driver only. Thus, it is believed that most people buried during the pandemic will have to be 'fetched' from the place where they died once the pandemic is over.

From when I was young I have noted that there are specific rituals that need to be performed for the spirit of the deceased can transition smoothly into the spirit world. The following are still adhered to. A goat is slaughtered to welcome the spirit of the deceased home from the mortuary. He has to be properly ushered into the homestead and informed that he has to stay at home and look after the family. The COVID-19 regulations do not allow gathering around an animal, dissecting it (ukuhlinza) and separating body organs (ukuhlahlela), so this ritual too has fallen off. Ukugeza isidumbu the washing of the body by the elders of the family is the most important funeral ritual. At midnight, the family uses special medication to wash the body one last time. Most families use special muti or intelezi to perform this task. It is believed that if the body is not washed, the departed person will come back and haunt the surviving members of the family wanting to be "washed". Currently under the COVID-19 regulations, the handling of the body is strictly forbidden, whether or not the person died of COVID-19 related illness. Extra caution has to be taken as bodies may be mixed in the mortuary. As a result the government has instructed funeral parlours to deliver the body in the morning, shortly before the funeral service begins. This is done in order to stop family members from handling the body. Traditionally, ukubamba ibhokisi (carrying the coffin) is designated for immediate family members and is considered as sacred. The first-born son of the deceased leads the procession whilst carrying the man's big shield (isihlangu) and an elderly man talking to the deceased over ihlamvu lomlahlankosi (the buffalo thorn tree branch) with the immediate family following close behind. Social distancing regulation dictates that the family keeps the distance between family members and that nobody should come too close to the coffin. The biggest concern is that the health department officials in personal protective equipment (PPE) are the ones who have to carry the coffin or in some instances become a part of the pallbearers, frustrating the bereaved.

To this day, any married man who dies has to be buried with isikhumba senkomo (cowhide) covering the coffin. The cow has to be slaughtered after the arrival of the body at home. It differentiates the married men from the unmarried ones. Isikhumba is about recognition of a man's achievements, status and prestige afforded to him by being umnumzane (a married man).

Zulu funerals are preceded by a night vigil (umlindelo) where the extended family, friends and neighbours come together and stay up the whole night before a person is buried. This gives them a chance to speak of the deceased freely, wash the body, clothe it accordingly, finish all the outstanding rituals whilst the elderly women guard the body and give relevant instructions on what needs to be done. After the washing of the body by the chosen members of the family 
all are afforded the opportunity to view the body and wail. This is believed to begin the grieving process, and allow family members to say their goodbyes properly and in private.

The family of the deceased usually has a cleansing ceremony; (ukukhumula inzilo) this is performed after a month in case of the death of baby, three months when an engaged person dies, six months if a married man died an unnatural death and after twelve months if a husband died of natural courses. In all these instances, an animal has to be slaughtered so that umswani (dung) and/or inyongo (bile) can be utilised to wash the bodies of the surviving family members. If this ritual is not performed, a dark cloud lingers over family members resulting in misfortunes befalling them until it is performed. They may have accidents, be attacked for no apparent reason, lose their belongings and/or be fired from work.

The bringing home the spirit (ukubuyisa) of the deceased after a year has passed since a person died marks the official end to the mourning period. This is a ritual of feasting and jubilation as the spirit of the deceased is brought home. After the rollercoaster ride of emotions brought on by the loss of a loved one, this ritual is about celebrating that a family member is now an ancestor and will look after the family. The slaughtering of a cow and a goat(s) is mandatory. This ritual is characterised by singing, dancing, (ukusina, ukugiya) and ululating (ukukikiza).

\section{Findings}

From the interviews conducted, it became clear that the enforcement of COVID-19 regulations has led to the suppression of emotions and lack of closure for the remaining family members. All these rituals prepare the family members emotionally and psychologically to accept the unacceptable feelings; that their loved one will only be with them in spirit from now on. The deep religious nature of the Zulu people demands that these rituals are performed so that the family can find peace and the religion be adhered to.

People who have buried their loved ones during the pandemic find their religious beliefs to be a sensitive issue which should be treated as such. Adherence to religious instruction provides solace for bereaved family members, as the funeral preparations and the rituals that go with them provide closure. The belief in the continuation of consoles the surviving family members. Whilst the thought that the deceased will not be properly ushered into the spiritual realm is largely disturbing but the COVID-19 regulations have to be adhered to. Family members worry about the deceased becoming an angry ancestor due to the non-performance of the necessary rituals. Similarly, their mourning and grieving are interrupted, hindering their healing. It became clear from the interviewees that healing and solace are deemed and felt as only occurring after the rituals are performed.

The suppression of funeral rituals is traumatic and anxiety inducing to family members who are determined to appease the living-dead and keep them on a pedestal. The surviving family members have genuine concerns about the COVID-19 regulations which prevent them from performing the burial rites as custom dictates. Some families have performed half the needed rituals with the hope that as the coronavirus subsides, they will be able to perform the outstanding rituals.

\section{Conclusion}

In the wake of the COVID-19 pandemic things have changed in various ways, such as the manner in which rituals are performed. The presence of the police at funerals to enforce the law, forces all members into submission. The dilemma between upholding the law for the greater good and the right to practise one's religion is salient. It is not a choice for any family to make but more what the law prescribes. Once the COVID-19 pandemic is over all these 
rituals will have to be performed in order to appease the living-dead and to usher them into the ancestry in a proper manner. As members can no longer be pallbearers the task of communicating with the deceased on the journey from the morgue to the graveside has become foremost. Members of the family can fetch the spirit of the deceased even if the corpse is not there, the most important thing is the mlahlankosi branch. The department of health needs to communicate the revised procedures to be followed by African Traditional Religion adherents to rectify the errors that occurred at the beginning of the lockdown. This process must be expedited in order to avoid further fear and confusion in communities.

\section{References}

Ademiluka, S.O. (2009). The sociological functions of funeral mourning: illustrations from the Old Testament and Africa. OTE,22(1), 9-20.

Akwa, T.E. \& Maingi, J.M. (2020). From Ebola to COVID-19: Reshaping funerals and burial rites in Africa. Journal of Healthcare Communications, 5(3), 1-3.

Awolalu, J.O. \& Dopamu, P.A. (1979). West African Traditional Religion. Ibadan: Onibon-Oje.

Barasa, M. \& Shitandi, A. (2020). Aspects of impact of COVID-19 on African Traditional burial systems: the case of Bukusu of Kenya's North-Western counties. Journal of Research and Innovation, 4(4), 388-397.

Berglund, A-I (1976). Zulu thought-pattern and symbolism. London: C Hurst \& Co Ltd.

Bockie, S. (1999). Death and the invisible powers. Bloomington: Indiana University Press.

Bryman, A. (2001). Social Research Methods. Oxford: Oxford University Press.

Cardoso, E. A., da Silva, B.C., dos Santos, J.H. \& Accoroni, A. G. \& dos Santos, M. A. (2020). The effect of suppressing funeral rituals during the COVID-19 pandemic on bereaved families. Revista Latino-Americana de Enfermagen, 28(3), 1-9.

Chihota, D.T. (2003). Funeral ritual among the Basuto: A study of the encounter between Christianity and Basuto traditional religion. Unpublished Masters dissertation. Pietermaritzburg: University of Natal.

Ekore, R.I. \& Lanre-Abass, B. (2016). Arican cultural concept of death and the idea of Advance care Directives. Indian Journal of Palliative Care 22(4): 369-372.

Gbenda, J.S. (2005). Eschatology in Tiv Traditional Religious Culture: An interpretative enquiry. Nsukka: Chuka Educational Publishers .

Hexham, I. (1987). Texts on Zulu Religion: Traditional Zulu ideas about God. Lewiston / Queenstown: The Edwin Mellen Press.

Idowu, E.B. (1962). Olodumare: God in Yoruba belief. Lagos: Longman.

Jaja, I.J., Madubuike, U.A. \& Jaja, C.I. (2020). Social distancing: how religion, culture and burial ceremony undermine the effort to curb COVID-19 in South Africa. Emerging Microbes \& Infections, 9(1), 1977-1079.

Magesa, L. (1997). African Religion: The moral traditions of abundant life. Maryknoll, New York: Orbis Books. 
Mbiti, J.S. (1969). African Religions and Philosophy. Nairobi: East African Educational Publishers.

Mokhutso, J. (2019). African traditional bereavement rituals amongst Methodist church members in Mamelodi, Pretoria. Unpublished Master of Theology dissertation. Bloemfontein: University of the Free State.

Mulambuzi, F.X. (1997). Beliefs in ancestral spirits: interpreting contemporary attitudes of the Baganda to the ancestors. Unpublished Masters dissertation. Pietermaritzburg: University Natal.

Ngubane, S.E. (2004). Traditional practices on burial system with special reference to the Zulu people of South Africa. Indilinga Journal of Indigenous Knowledge Systems,3(2),171-177.

Nyawose, T.Z. (2000). 'Living in two worlds' codes and modes of expression at Zulu funerals in KwaZulu-Natal at the turn of the millennium. Unpublished Masters dissertation. Durban: University of Natal

Nwachuku, D. (1994). Rituals and symbols in the healing of infertility in Africa: Pastoral Counselling response. In S. Lartey, D. Nwachuku \& K. Wa Kasongo (eds.), Church and Healing: Echoes from Africa. Frankfurt: Peter Lang, 68-88.

Olupona, J.K. (2000). African spirituality: Forms, Meaning and Expression. New York: The Crossroad Publishing Company.

Omonisi, A.E. (2020). How COVID-19 pandemic is changing the Africa's elaborate burial rites, mourning and grieving. Pan African Medical Journal, 35(2), 1-4.

Onu, J.O. (2019).. A functional-semiotic investigation of traditional funeral rites and rituals in Elugwu Ezike in Igboland. International Journal of language Studies, 13(1), 99-128.

Parrinder, A. (1954).. African traditional, Religion. London: Hutchinson University Library

Shino, W. (1997). Death and Rituals among the Luo in South Nyanza. African Study Monographs, 18(3), 213-228.

Souza, C.P. \& Souza, A.M. (2019). Funeral rituals in the process of mourning: meaning and functions. Psicologia: Teoria e Pesquisa, 35, 1-7.

Zungu, E.B. (2016). 'Direct indirectness: evidence of ancestral veneration in personal names within traditional polygynous families in KwaMambulu, Kranskop'. Nomina Africana,30(2), 89103

Zungu, E.B. (2021). Zulu names, polygyny and Gender Politics in Traditional Societies. Pietermaritzburg: UKZN Press 